\title{
Kahoot! as a Gamification Tool in Vocational Education: More Positive Attitude, Motivation and Less Anxiety in EFL
}

\author{
Merve SERCANOĞLU 1 (D) Yusuf İslam BOLAT ${ }^{* 2}$ (D) İdris GÖKSU3 (D) \\ ${ }^{1}$ Ministry of National Education, İstanbul, Turkey, mrosrcngl@icloud.com \\ ${ }^{2}$ Kahramanmaraş İstiklal University, Kahramanmaraş, Turkey, y.islambolat@gmail.com \\ ${ }^{3}$ Mardin Artuklu University, Mardin, Turkey, idrisgoksu@artuklu.edu.tr \\ * Corresponding Author: y.islambolat@gmail.com
}

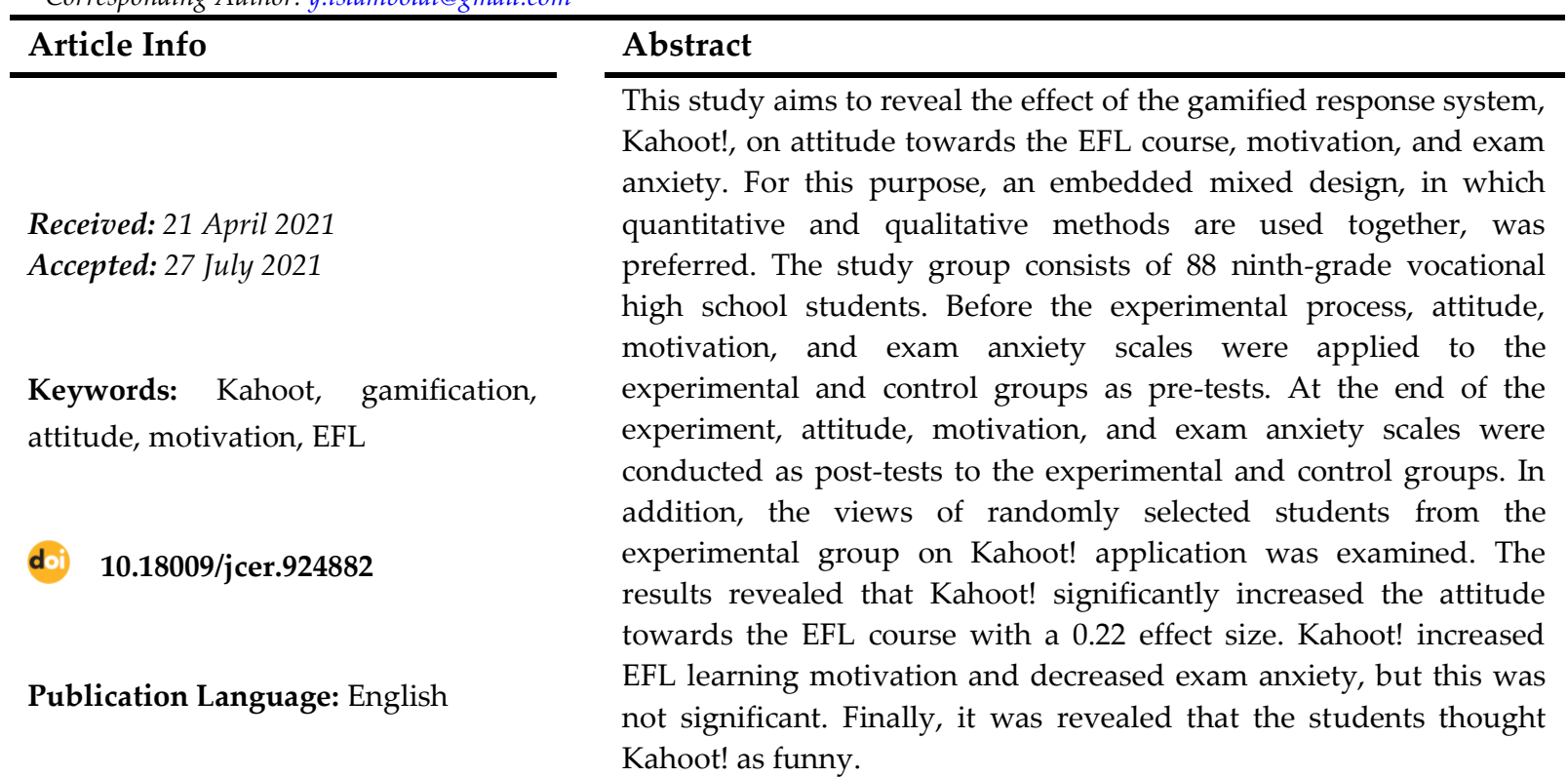

open access (a) CrossMark (C)

To cite this article: Sercanoğlu, M., Bolat, Y. İ., \& Göksu, İ. (2021).

Kahoot! as a gamification tool in vocational education: More positive attitude, motivation and less anxiety in EFL. Journal of Computer and Education Research, 9 (18), 682-701. DOI: 10.18009/jcer.9224882

\section{Introduction}

The rapid change in instructional technologies enables the emergence of new teaching techniques in language teaching. Especially, the development of Web-based systems and the reduction of internet access barriers to a minimum level required the implementation of these techniques. Since the 1980s, much research has been conducted using technology in foreign language teaching (Thorne, Black, \& Sykes, 2009). Figueroa Flores (2015) argues that foreign language teachers need new strategies to increase students' motivation and interest in foreign language teaching. Many researchers like Flores now support the use of technology in education to make learning meaningful. Chun, Kern, and Smith (2016) state that technology increases creativity and intellectual capacity. Having a progressive view on the meaningful use of technology in education, Prensky (2001) states that children have the 
digital language of the internet, computer, and video games. They spend most of their time with games and argue that students' learning should be supported. Kessler (2018) also suggests that technology should be included in education for effective learning because it has become difficult to motivate students with traditional methods (Premarathne, 2017).

Digital game-based learning (DGBL), one of the increasingly popular teaching methods in recent years, is beneficial in education in many respects. DGBL motivates students in the teaching process and is thought to increase engagement and interest. DGBL is an instructional approach in which computer use is supported for educational purposes (Mavridis \& Tsiatsos, 2017). Many software designers and commercial companies hope to make academic learning more fun by developing games for learning (Kafai, 2006). Because game-based learning includes the discipline of the game and aims to involve the student in the learning process and increase learning performance (Graham, 2015). According to the report of the world-famous The New Media Consortium (NMC), which provides reports on the development of technology every year, educational games develop critical thinking, problem-solving, and group work, as well as the ability to solve the complexity of social and environmental contrasts (Johnson, Adams Becker, Estrada, \& Freeman, 2014). Gee (2003) suggests that motivation can be provided through games, and its continuity can be learned. Game-based learning performs three tasks; encouraging learning, developing knowledge, and increasing skills (McFarlane, Sparrowhawk, \& Heald, 2002). The digital games used in education show their effects in all areas of education. Indeed, Kebritchi, Hirumi, and Bai (2010) argued that digital games increase mathematics achievement; Zin, Jaafar, and Seng Yue (2009) suggest that students who found history courses boring can become more fun with digital games. Papastergiou (2009) suggested that digital games positively affect physics and health education in terms of engagement. Many researchers claim that digitalbased games, which are more promising in foreign language education, have an important effect. Thomas (2012) argues that language learning through digital-based games provides success-oriented learning. Therefore, the use of digital games in the classroom can support cognitive development. It has been suggested that a carefully chosen game allows people to measure their status in terms of cognitive and behavioral development and motivation in the process of learning a foreign language (Cornillie, Thorne, \& Desmet, 2012). Hubbard (2009) argues that digital games provide new information and skills to students in modern foreign language teaching methods and reinforce this information even without teachers. 
One of the applications that carry education to digital platforms is gamified student response systems. Gamified Web 2.0 tools such as Kahoot!, Plickers, Quizizz, ClassDojo, Classcraft, and Socrative have become popular in teaching processes in recent years. The reasons why gamification is popular in education can be evaluated as having a positive effect on motivation (Özkan \& Samur, 2017) and encouraging active learning (Iaremenko, 2017). Gamified Web 2.0 tools are Web-based applications where the teacher prepares interactive questions about the course and presents them to students. Rather than the traditional response system used in the classroom, the gamified student response system was more attractive and motivating for students (Wang, 2015) and had a more positive effect as an educational tool (Rosas et al., 2003). While the traditional student response system is a useful method for measuring the cognitive status of students for the teacher, gamified response systems are more exciting and motivating for students during the exam (Wang, 2015). Gündüz and Akkoyunlu (2020) suggested that teachers' using classroom response systems while planning class activities can increase motivation for the course. Bury (2017) researched online assessment tools and concluded that they provide immediate feedback and improve students' grammar knowledge.

The most popular of the gamified student response systems used in education is Kahoot! (Ismail \& Mohammad, 2017; Plump \& LaRosa, 2017; Wang \& Tahir, 2020). Kahoot! is an application used mostly in the formative evaluation process (Alsancak-Rowkaya, 2017; Şad \& Özer, 2020). The Kahoot! application we investigated in this study is an application that is easy to use for teachers and does not require an intensive preparation phase before. They can create game-based quizzes, discussions, and surveys using the application (Plump \& LaRosa, 2017). By presenting the teacher's questions before, the students answer the questions and collect scores using tablets, phones, or computers. After the questions are answered, the students' rank and student answers are reflected on the screen. Educators have preferred multiple-choice questions for years due to their usefulness and have become interactive with Web 2.0 tools like Kahoot! (Howell, Tseng, \& Colorado-Resa, 2017).

Kahoot! can increase students' motivation when teaching (Al-Hadithy \& Ali, 2018; Purba, Sormin, Harefa, \& Sumiyati, 2019). In addition, Al-Hadithy and Ali (2018) integrated Kahoot! into the learning environment and found an increase in students' engagement, selfefficacy, and independent learning. According to Wang (2015), Kahoot! application is more attractive and motivating as it provides a competitive environment for students. However, it 
has been suggested that sometimes Kahoot!'s causing extreme competition may lead to negative consequences (Licorish, Owen, Daniel, \& George, 2018). Bolat, Şimşek, and Ülker (2017) in their study with university students concluded that formative assessment activities were carried out with Kahoot! contributed to affective and cognitive skills. Orhan-Göksün and Gürsoy (2019) have found Kahoot! to be effective in academic success and engagement.

When the literature is examined, it is seen that many studies are examining the effect of Kahoot!. In a new review study, the researches examining Kahoot! were investigated, and it was concluded that Kahoot! mostly increased motivation and engagement (Wang \& Tahir, 2020). Another result of the related study was the effectiveness of Kahoot! in learning a foreign language. Kahoot! also offers an effective strategy in terms of providing a fun environment in English education (Putri, 2019; Yürük, 2020), improves Arabic language grammar knowledge and motivation (Eltahir, Alsalhi, Al-Qatawneh, AlQudah, \& Jaradat, 2021), increases engagement (Budiati, 2017), and especially helps students in concept teaching (Medina \&Hurtado, 2017; Plump \& LaRosa, 2017). It benefits educators as well as students (Zengin, Bars, \& Şimşek, 2017). Kahoot!, used as a measurement tool by teachers, can positively affect students' exam anxiety by gamifying the evaluation process in education and moving it to a digital platform. According to a study, including gamification in the evaluation process allowed students to reduce their exam anxiety (Isbister, Karlesky, Frye, \& Rao, 2012). In this study, the effect of Kahoot! on motivation, attitude, and exam anxiety in English as a foreign language (EFL) teaching was investigated in the sample of vocational high schools. In this context, the research questions are as follows:

1. Does Kahoot! have a significant effect on students' motivation in learning English?

2. Does Kahoot! have a significant effect on students' exam anxiety?

3. Does Kahoot! have a significant effect on students' attitudes towards EFL courses?

4. What are the student views about Kahoot! application?

\section{Method}

\section{Research Design}

This study aims to examine the effect of Kahoot!, a gamified online response system, on students' exam anxiety, motivation, and attitudes. For this purpose, an embedded mixed design, in which quantitative and qualitative methods were used together, was used. In the embedded mixed research method, the quantitative or qualitative approach is more dominant, and the research is largely qualitative or quantitative (Yıldırım \& Şimşek, 2013). 
This research method can be used in cases where quantitative data collected while answering the research questions are desired to be enriched with qualitative data (Creswell, 2013). In this study, quantitative data obtained with quasi-experimental design were interpreted by supporting them with student views. The research process is presented in Figure 1.

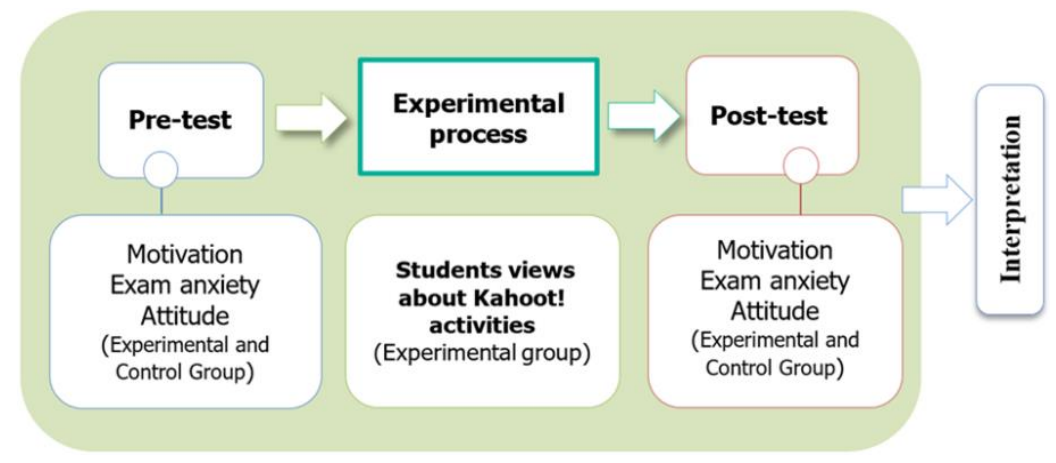

Figure 1. The research process.

As shown in Figure 1, the Motivation Scale in English Language Learning, the Attitude Scale Towards the English Course, and the Exam Anxiety Scale were applied as pretests. Then, a 10-week application period was carried out. After the experiment, all three scales were used as post-test. After the experimental process, the views of the four randomly selected students from the experimental group regarding the activities performed by the Kahoot! application were taken.

\section{Study Group}

The study group of the research consists of ninth grade (the first grade of high school) students in four different classes studying at a vocational high school in Mardin in 2019 (the second semester). We used the convenience sampling method while specifying the study group. The classes are similar in terms of academic characteristics, and their English course teacher is the same person (the first author). Two of the classes were randomly allocated as the experimental group $(\mathrm{N}=44)$ and two as the control group $(\mathrm{N}=44)$. All of the participants were male because it was a boys' high school.

\section{Experimental Process}

Both the experimental and control groups took English courses by the same teacher for five hours a week for ten weeks. The experimental process was carried out by the first author of the study, a teacher in the relevant high school. To summarize the concepts learned in the course and reinforce the learning during the week, the students in the experimental group were applied gamified online quizzes using the Kahoot! application at the fifth hour. 
The quizzes prepared by the teacher were reflected from the smartboard, and students accessed the exam with their quiz passwords. Each quiz consists of 20 questions in total. Throughout the experimental process, the Ministry of National Education ninth grade second semester English course curriculum was followed. Within the scope of that curriculum, the topics of "6. Bridging culture", "7. World heritage", "8. Emergency and health problems", "9. Invitations and celebrations", and "10. Television and social media" were covered. Two quizzes were applied for each subject, and a total of 10 quiz activities were carried out during ten weeks. It has been reported that the students who are in the top five will gain five points for their verbal grades to ensure active engagement before these activities are implemented. In Figure 2, a one-week course process carried out in the experimental group is presented.

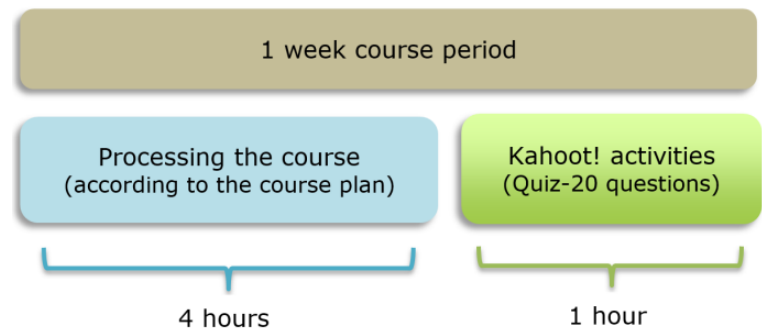

Figure 2. Experimental process.

\section{Data Collection Tools}

To collect the quantitative data of the research, the Attitude Scale Towards the English Course (Takkaç-Tulgar, 2018), Motivation Scale in English Language Learning (Mehdiyev et al., 2017) and The Revised Exam Anxiety Scale developed by Benson and ElZahhar (1994) and adapted to Turkish by Akın, Demirci, and Arslan (2012), were used. The Motivation Scale in English Language Learning consists of self-confidence, attitude, and personal use dimensions and 16 items. The scale was developed as a five-point likert type. Answers to the items were scored as (1) for "Never agree", (2) for "Partially agree", (3) for "Moderately agree", (4) for "Mostly agree" and (5) for "Totally agree". There are four reverse items in self-confidence and two in attitude dimensions. Therefore, a total of six items were reverse coded. The validity and reliability analysis of the scale were made, and the internal consistency reliability test result was found as $\alpha=.83$. The Revised Exam Anxiety Scale consists of four dimensions: tension, physical symptoms, anxiety and thoughts unrelated to the exams, and 20 items. The scale is scored in four levels as (1) "Never", (2) "Sometimes", (3) "Mostly", and (4) "Always". Scale items were developed as negative expressions. Therefore, 
the exam anxiety level was interpreted high as the score obtained from the scale increased, and exam anxiety was interpreted low as the score obtained from the scale decreased. The validity and reliability analysis of the scale were made, and the internal consistency reliability test result was found as $\alpha=.88$. The Attitude Scale Towards the English Course consists of four dimensions: interest, importance, contribution, and informationentertainment, and 26 items. The scale is a five-point likert type, and the scores range from "1: I never agree" to "5: I totally agree". All items were positively expressed on the scale. Validity and reliability analysis of the scale were made, and the internal consistency reliability test result was found as $\alpha=.96$.

\section{Data Analysis}

Two-factor analysis of variance is a method that analyzes pre-test and post-tests simultaneously with group variables. In this study, two-factor analysis of variance (Mixed ANOVA) for mixed measurements was used since the scores of experimental and control groups will be interpreted according to the pre-test and post-test scores (Can, 2014). The assumptions of the two-way analysis of variance were tested, and the data were found to meet these assumptions. When deciding on the analysis of the quantitative data of the research, the assumptions of the two-way analysis of variance were taken into account. The normal distributions of the data were examined with Kurtosis-Skewness values, Kolmogorov-Smirnov test, and Histogram graphics. Kolmogorov-Smirnov test results are presented in Table 1.

Table 1. Kolmogorov-Smirnov test results.

\begin{tabular}{|c|c|c|c|c|}
\hline \multirow{2}{*}{ Test/Scale } & \multirow{2}{*}{ Group } & \multicolumn{3}{|c|}{ Kolmogorov-Smirnov } \\
\hline & & Statistic & $\mathrm{df}$ & $p$ \\
\hline \multirow{2}{*}{ Pre-test/Motivation } & Experimental & 0.10 & 44 & $0.20^{*}$ \\
\hline & Control & 0.11 & 44 & $0.20^{*}$ \\
\hline \multirow{2}{*}{ Pre-test/Anxiety } & Experimental & 0.08 & 44 & $0.20^{*}$ \\
\hline & Control & 0.10 & 44 & $0.20^{*}$ \\
\hline \multirow{2}{*}{ Pre-test/Attitude } & Experimental & 0.08 & 44 & $0.20^{*}$ \\
\hline & Control & 0.11 & 44 & 0.14 \\
\hline \multirow{2}{*}{ Post-test/Motivation } & Experimental & 0.07 & 44 & $0.20^{*}$ \\
\hline & Control & 0.07 & 44 & $0.20^{*}$ \\
\hline \multirow{2}{*}{ Post-test/Anxiety } & Experimental & 0.08 & 44 & $0.20^{*}$ \\
\hline & Control & 0.11 & 44 & $0.20^{*}$ \\
\hline \multirow{2}{*}{ Post-test/Attitude } & Experimental & 0.10 & 44 & $0.20^{*}$ \\
\hline & Control & 0.11 & 44 & 0.15 \\
\hline
\end{tabular}


When Table 1 is examined, it is seen that the data of the pre-test and post-tests of the experimental and control groups showed normal distribution. The content analysis method was used in the analysis of the qualitative data of the research. Content analysis is an inductive analysis method based on coding revealing the facts underlying the data (Patton, 1990). In content analysis, the data are coded and organized within the framework of certain themes and concepts and interpreted in a way that the reader can understand (Yildirım \& Şimşek, 2013). Draw.io software was used during the visualization of qualitative findings. The qualitative data were analyzed by the researchers and interpreted with direct citations. The intercoder reliability method was used to ensure the reliability of the content analysis. In addition, to increase the validity and reliability of the research, the study spread over ten weeks in total, so the innovation effect was prevented.

\section{Finding}

\section{The Effect of Kahoot! on Students' EFL Learning Motivation}

Two-way analysis of variance was used to analyze the pre-test and post-tests of the experimental and control groups to examine the effects of using classroom assessment activities with Kahoot! in the ninth-grade English course on students' EFL learning motivation. The descriptive statistics obtained from the analysis are presented in Table 2, and the significance results are presented in Table 3. In addition, the change in the pre-test and post-test scores of the groups is given in Figure 3.

Table 2. The pre-test and post-test descriptive statistics of EFL learning motivation.

\begin{tabular}{lllll}
\hline Group & & $M$ & $S D$ & $N$ \\
\hline \multirow{4}{*}{ Pre-test motivation } & Experimental & 3.35 & 0.93 & 44 \\
& Control & 3.34 & 0.60 & 44 \\
& Total & 3.35 & 0.78 & 88 \\
\hline \multirow{3}{*}{ Post-test motivation } & Experimental & 3.73 & 0.77 & 44 \\
& Control & 3.44 & 0.82 & 44 \\
& Total & 3.59 & 0.81 & 88 \\
\hline
\end{tabular}

As it is seen in Table 2, students' EFL learning motivation scores for experimental group are found $M_{\text {pre }}=3.35$ and $M_{\text {post }}=3.73$; for control group $M_{\text {pre }}=3.34$ and $M_{\text {post }}=3.44$. According to this result, similar changes occurred in both groups. To show whether this situation has a significant effect between the two groups, two-way analysis of variance results is given in Table 3 . 
Table 3. The effect of Kahoot! on EFL learning motivation.

\begin{tabular}{lcccccc}
\hline Source of variance & Sum of squares & $d f$ & Mean of square & $F$ & $p$ & Partial $\eta^{2}$ \\
\hline Between Groups & & & & & & \\
Group & 1.021 & 1 & 1.02 & 1.51 & 0.22 & 0.02 \\
Error & 58.187 & 86 & 0.677 & & & \\
\hline Within Groups & & & & & & \\
Measurement & 2.49 & 1.00 & 2.49 & 4.35 & 0.04 & 0.05 \\
Measurement* Group & 0.82 & 1.00 & 0.82 & 1.44 & 0.23 & 0.02 \\
Error & 49.20 & 86.00 & 0.57 & & & \\
\hline
\end{tabular}

As seen in Table 3, there is no significant difference between the experimental and control groups $(F=1.51, p=.22)$ at the significance level of $p=.05$. The fact that the partial effect size $\left(\eta^{2}=0.02\right)$ of the group variable is very close to zero confirms this situation. In Figure 3, the graphic of the change in both groups' pre-test and post-test motivation scores is presented.

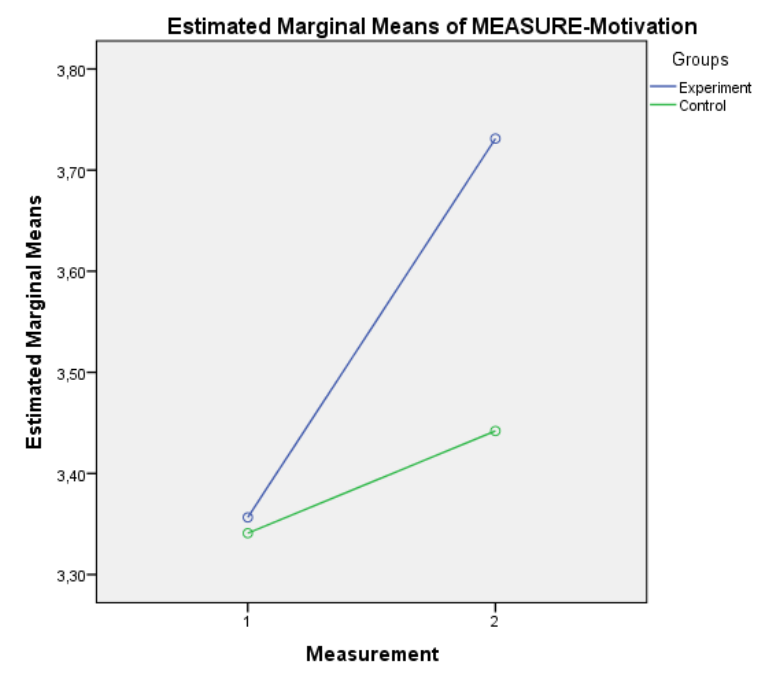

Figure 3. Distribution of motivation scores of experimental and control groups.

As seen in Figure 3, the experimental group's motivation increased more than the control group. Based on this result, it can be claimed that the activities carried out with Kahoot! have no significant effect on the students' EFL learning motivation. However, the change in motivation score means does not have a significant impact.

The Effect of Kahoot! on Students' Exam Anxiety

Two-way analysis of variance was used to analyze the pre-test and post-tests of the experimental and control groups together to examine the effects of using classroom assessment activities with Kahoot! in the ninth grade EFL course on students' exam anxiety. 
Descriptive statistics and significance results obtained from analyzes are given in Table 4 and Table 5. In addition, the distribution of pre-test and post-test scores is presented in Figure 4.

Table 4. The pre-test and post-test descriptive statistics of exam anxiety.

\begin{tabular}{llccc}
\hline Group & & $M$ & $S D$ & $N$ \\
\hline \multirow{4}{*}{ Pre-test exam anxiety } & Experimental & 2.41 & 0.56 & 44 \\
& Control & 2.22 & 0.51 & 44 \\
& Total & 2.31 & 0.54 & 88 \\
\hline \multirow{3}{*}{ Post-test exam anxiety } & Experimental & 2.20 & 0.56 & 44 \\
& Control & 2.26 & 0.51 & 44 \\
& Total & 2.23 & 0.53 & 88 \\
\hline
\end{tabular}

As shown in Table 4, the exam anxiety scores of the students were found for the experimental group as $M_{\text {pre }}=2.41$ and $M_{\text {post }}=2.20$; for the control group, $M_{\text {pre }}=2.22$ and $M_{\text {post }}$ $=2.26$. According to this finding, it can be claimed that exam anxiety decreased in the experimental group. However, it increased in the control group. Two-way analysis of variance is given in Table 5 to show whether this situation has a significant difference between the two groups.

Table 5. The effect of Kahoot! on exam anxiety.

\begin{tabular}{lcccccc}
\hline Source of variance & Sum of squares & $d f$ & Mean of square & $F$ & $p$ & Partial $\eta^{2}$ \\
\hline Between Groups & 0.17 & 1 & 0.17 & 0.68 & 0.41 & 0.01 \\
Group & 22.01 & 86 & 0.25 & & & \\
Error & & & & & & \\
\hline Within Groups & 0.315 & 1 & 0.31 & 0.96 & 0.33 & 0.01 \\
Measurement & 0.694 & 1 & 0.69 & 2.12 & 0.15 & 0.02 \\
Measurement* Group & 28.095 & 86 & 0.327 & & & \\
Error &
\end{tabular}

As seen in Table 5, there is no significant difference between the experimental and control groups $(F=0.68, p=0.41)$ at the significance level of $p=.05$. The fact that the partial effect size $\left(\eta^{2}=0.01\right)$ of the group variable is also very close to zero confirms this situation. In support of this result, the exam anxiety change in both groups' pre-test and post-test is shown in Figure 4. 


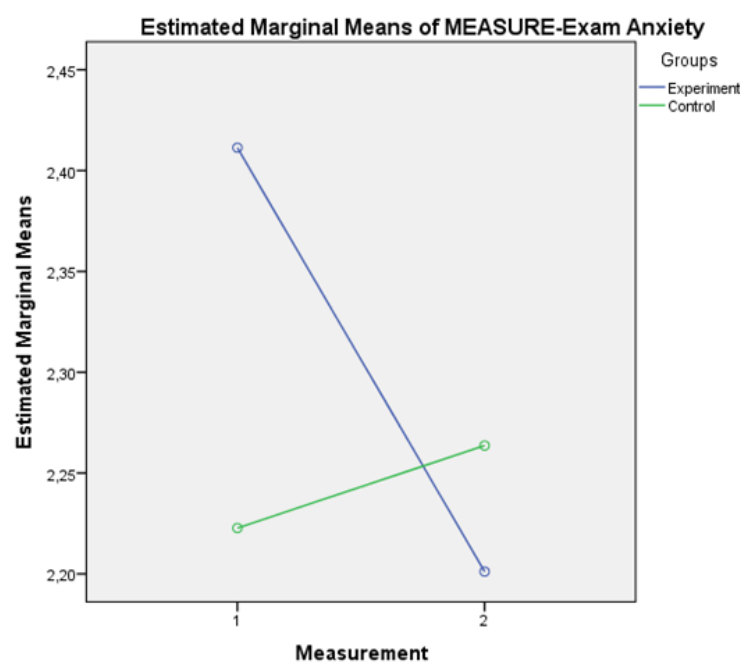

Figure 4. Distribution of exam anxiety scores of experimental and control groups.

As seen in Figure 4, while the exam anxiety of the experimental group decreased, the control group increased slightly. However, this change in the exam anxiety of the experimental and control groups does not have a significant effect. Based on this finding, it can be claimed that the activities carried out with Kahoot! do not have a significant impact on exam anxiety.

\section{The Effect of Kahoot! on Students' Attitudes Towards EFL Course}

Two-way analysis of variance was used to analyze the pre-test and post-tests of the experimental and control groups to examine the effects of using classroom assessment activities with Kahoot! in the ninth grade EFL course on students' attitudes towards the EFL course. Descriptive statistics and significance results obtained from analyzes are given in Table 6 and Table 7. In addition, the distribution of pre-test and post-test scores is presented in Figure 5.

Table 6. The pre-test and post-test descriptive statistics of attitude.

\begin{tabular}{lllll}
\hline Group & & $M$ & $S D$ & $N$ \\
\hline \multirow{3}{*}{ Pre-test Attitude } & Experimental & 3.12 & 0.90 & 44 \\
& Control & 3.35 & 0.81 & 44 \\
& Total & 3.23 & 0.86 & 88 \\
\hline \multirow{3}{*}{ Post-test Attitude } & Experimental & 4.21 & 0.48 & 44 \\
& Control & 3.26 & 0.87 & 44 \\
& Total & 3.74 & 0.85 & 88 \\
\hline
\end{tabular}

As shown in Table 6, the students' attitudes towards the EFL course are found for the experimental group as $M_{\text {pre }}=3.12$ and $M_{\text {post }}=4.21$; for control group $M_{\text {pre }}=3.35$ and $M_{\text {post }}=$ 
3.26. According to this finding, the experimental group's attitude towards the EFL course increased, but the control group decreased slightly. To show whether this situation has a significant effect between the two groups, the results of two-way analysis of variance are given in Table 7.

Table 7. The effect of Kahoot! on attitude towards EFL course.

\begin{tabular}{lcccccc}
\hline Source of variance & Sum of squares & $d f$ & Mean of square & $F$ & $p$ & Partial $\eta^{2}$ \\
\hline Between Groups & & & & & & \\
Group & 5.542 & 1 & 5.542 & 9.61 & 0.003 & 0.10 \\
Error & 49.607 & 86 & .577 & & & \\
\hline Within Groups & & & & & & \\
Measurement & 11.338 & 1 & 11.338 & 17.47 & 0.00 & 0.17 \\
Measurement* Group & 15.405 & 1 & 15.405 & 23.73 & 0.00 & 0.22 \\
Error & 55.820 & 86 & 0.645 & & & \\
\hline
\end{tabular}

As seen in Table 7, a significant difference was found between the experimental and control groups $(F=9.61, p=0.003)$ at the significance level of $p=.05$. The partial effect size of the group variable was found to be $\eta^{2}=0.10$. When the impact of Kahoot! on attitude was calculated with the pre-test and post-test measures, the effect size was 0.22 . This finding shows that the group variable causes $22 \%$ of the variance in students' attitudes. In support of this finding, Figure 5 shows the distribution of the pre-test and post-test measurements of both groups' attitudes toward the EFL course.

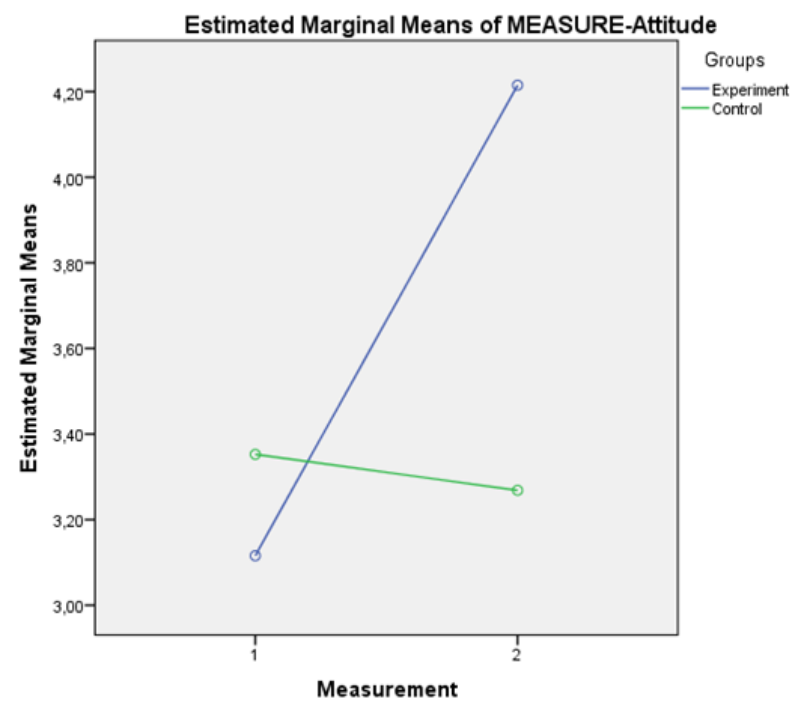

Figure 5. Distribution of attitude scores of experimental and control groups.

As seen in Figure 5, while the attitude of the experimental group students towards the course increased, the control group decreased slightly. Based on this finding, it can be 
claimed that the activities carried out with Kahoot! significantly increased the attitude towards the English course.

\section{Students' Views about Kahoot! Application}

The views of the students about the Kahoot! application used in the 10-week EFL learning process were consulted, and the obtained codes are presented in Figure 6. Accordingly, the following codes are obtained; funny, providing effective learning, offering equal opportunities, remembering in the exam, usefulness, providing permanent learning, and creating a competitive environment.

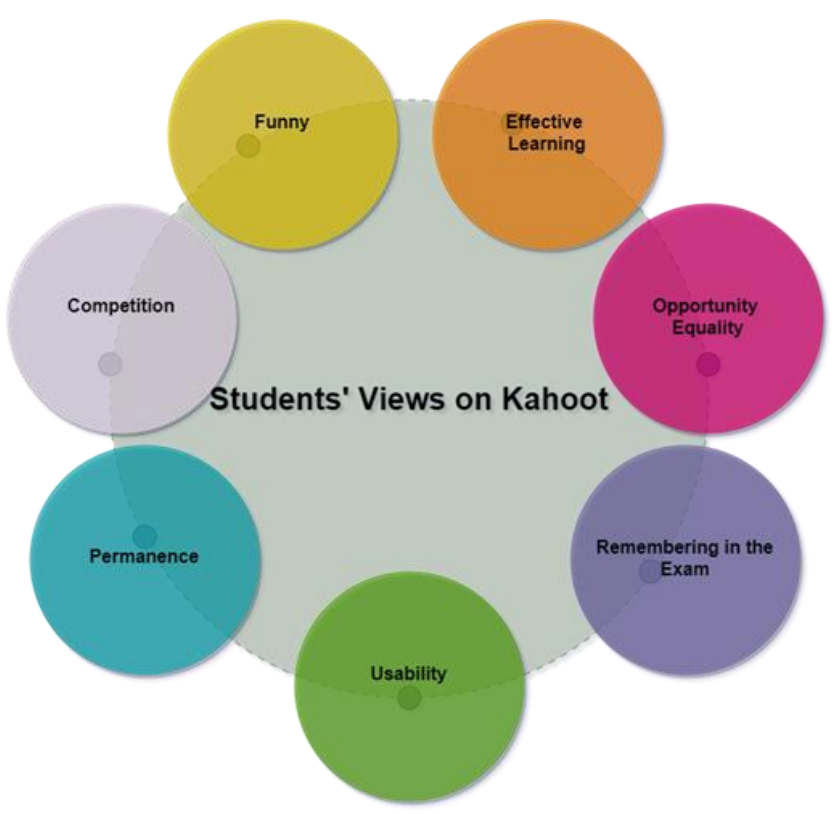

Figure 6. Student views about Kahoot.

When the codes in Figure 6 are examined, it can be said that students are satisfied with the use of Kahoot! in EFL courses and the views are positive. In these views, the students emphasized Kahoot! app's features of permanence, effective learning, and remembering at the time of exam. In addition, motivational elements such as being fun and creating a competitive environment in the classroom have been focused. It can be interpreted that this situation can support the motivation of students towards EFL courses. Kahoot! 's being useful and offering equal opportunities among students may also be effective in students' developing ideas favoring using this application more in EFL courses. The direct expressions of the students regarding these codes are presented in the following section.

The participant students expressed their views related to the code of Kahoot!'s effective learning as follows: F. Y.: "It is an application that we can raise the level of English both by having fun and learning.", Y. Ü.: "I have positive, fun, and instructive thoughts about 
Kahoot! application" and O. E.: "It is a very educational and guiding application". Related to the code of permanence, Ş. A. expressed his view as: "Because sometimes it was permanent in our minds when a word was repeated more than once. But if it was shown only once, we could only remember these words instantly. We started to keep the words better in our minds". Related to the code of giving an advantage in the exam, Ş. A. stated: "We could find these words in the exams questions. So, we were a bit more advantageous". Related to the code of fun, the students emphasized this aspect of Kahoot! as follows; F. Y.: "It is an application that we can raise our level of English by having fun and learning", O. E.: "I don't think anyone will get bored. There is nothing funny like learning through play", Y.Ü.: "I think positive, fun, and instructive things about Kahoot! application". Kahoot! 's feature of creating classroom competition was emphasized with this word; Y. E. Ü.: "In this application, we both had fun, learned and competed with each other. In this way, we learned in the classroom with a sweet competition". Related to Kahoot! 's being a useful application for English course is expressed as follows; Ş.A.: "It is a good application, and everyone can use it easily". Related to the Kahoot! 's enabling equal opportunities in the classroom, O.E. stated: "We have observed that even the unsuccessful students can learn something. Because it can teach even those, who don't know well. There were a lot of students in our class who didn't know English, but even they learned". By these statements, they emphasized it enabling the opportunity of learning for relatively unsuccessful students.

\section{Discussion and Conclusion}

In this study, it is aimed to examine the effect of the online response system Kahoot! application, which was applied in the ninth grade EFL course in vocational high school, on students' motivation, attitudes and exam anxiety towards the course, as well as student views on these activities they experienced. The research data were obtained from a study group of 88 students at a vocational high school in Mardin. The results of the research are limited to the answers given by the students to the scales and interview questions, and the activities carried out within the scope of five topics in 2019 (the second semester) ninth-grade textbook as; (6. Bridging culture, 7. World heritage, 8. Emergency and health problems, 9. Invitations and celebrations and 10. Television and social media). Besides, Kahoot! application was used to summarize and reinforce the learnings in the last hour of the week. The results of the research should be evaluated within these limitations. According to the 
first research question of the study, the in-class gamified assessment activities were carried out with Kahoot! increased the motivation of the experimental group students in the EFL course more than the control group, but this increase did not make a significant difference.

Many studies have revealed that Kahoot! has a positive effect on motivation (AlHadithy \& Ali, 2018; Gündüz \& Akkoyunlu, 2020; El-tahir et al., 2021; Purba et al., 2019). It is thought that Kahoot! affects motivation because it provides a gamification environment. Because gamified student response systems are attractive to students (Wang, 2015) and positively affect motivation (Özkan \& Samur, 2017; Wang, 2015). Indeed, the expression of O. E. "I do not think anyone will get bored. There is nothing funny like learning through play" supports this finding. Although Kahoot! increases motivation in our study, this increase is not significant. The reason for this situation may be applying Kahoot! activities in the last hour of the courses. The tiredness of students may also have affected the result.

According to the study's second research question, the effects of classroom gamified assessment activities on Kahoot! on students' exam anxiety were examined. Kahoot! activities reduced the exam anxiety of the experimental group students. However, according to the analyzes conducted on the pre-test and post-tests of the experimental and control groups, it was observed that Kahoot! did not significantly reduce exam anxiety. No experimental results were encountered, revealing the effect of Kahoot! on exam anxiety. However, it has been determined that there are many studies related to general anxiety. Compiling these studies, Wang and Tahir (2020) found that Kahoot! positively affects students' anxiety. Susanti (2018) found that students who use Kahoot! in English courses are not worried because they find Kahoot! interesting. In another study, gamification in the evaluation process reduced exam anxiety (Isbister et al., 2012). Also, Nkhoma, Nkhoma, Thomas, Tu, and Le (2018) claimed that Kahoot! removed stress and brought fun to the class. Our study focused on the exam anxiety variable, but in the literature, it is seen that the research on Kahoot! focused on the variable of general anxiety. Since Kahoot! is a response system, it is thought to be important that new experimental studies revealing the effect of Kahoot! should be carried out with different samples (e.g., primary school, secondary school, higher education, high schools out of vocational high schools, etc.). Although some of the teachers are reluctant to use Kahoot! because it is an application that focuses on points, scoreboard, and winning, these concerns turned out to be unfounded (Wang \& Tahir, 2020). 
According to the third research question of the study, the effect of Kahoot! on attitude towards EFL courses was examined. As a result of the analysis made for this purpose, it was revealed that the evaluation activities were carried out with Kahoot! significantly increased the attitudes of the experimental group students towards the EFL course compared to the control group. Studies investigating the effect of Kahoot! on students have revealed that Kahoot! has a positive effect on teachers' and students' attitudes and increases engagement (Wang \& Tahir, 2020). Yürük (2020) found that Kahoot! positively affects students' EFL pronunciation skills. As a matter of fact, students with positive attitudes are expected to participate in the lesson. According to Md. Yunus and Nur Rashidah Khairunnisa (2011), a positive attitude and higher motivation may occur in learning English when supporting environmental factors are provided to students. In our study, the fact that the teacher gave additional points to the top five students in the 10-week experimental process may have increased the students' attitudes. Gamification-based teaching practices positively affect students' attitudes (Yildirim, 2017). In addition, the proven effectiveness of Kahoot! in English courses (Wang \& Tahir, 2020) supports these results.

The quantitative results of the study have shown that Kahoot! increases both the attitude towards EFL course and EFL learning motivation and reduces exam anxiety. However, there was a significant difference only in terms of attitude towards the EFL course. Students' views also support these results. As a matter of fact, students pointed out especially the fun features of Kahoot!. These findings are in parallel with the results in the literature. Kahoot! offers an effective strategy to provide a funny environment in English teaching (Putri, 2019; Yürük, 2020) and increases engagement (Budiati, 2017). Also, in our study, it was understood that students thought Kahoot! contributed to permanent learning, provided an advantage in exams, and created a competitive environment. Views expressing that Kahoot! has a user-friendly interface were also put forward. It can be claimed that Kahoot! is motivating because it provides a competitive environment (Wang, 2015). However, it should not be forgotten that sometimes Kahoot!'s extreme competition may lead to negative consequences (Licorish et al., 2018). Therefore, it may be beneficial for teachers to consider this situation while using Kahoot!. It may be useful for teachers to use it only in a formative manner so that competition does not cause concern. All these results indicate that if Kahoot! is used in EFL courses in vocational high schools, it will increase the interest in the course. In addition, these results are expected to be reflected in academic achievement. 
Eltahir et al. (2021) used Kahoot! as a game-based online assessment tool and determined that Kahoot! improved the Arabic language grammar knowledge and students' motivation. Because students' high motivation or positive attitudes may affect academic achievement (Good \& Brophy, 2000). Accordingly, Bury (2017), who researched online assessment tools, revealed that these tools improve students' grammar knowledge.

As a result, with this experimental study, we tried to reveal the effect of Kahoot! on EFL learning in vocational high schools. As a result of this study, we conducted it within the framework of the EFL course; it has been proved that enriching the courses with Kahoot! activities significantly affects the attitude towards the EFL course. According to this result, in addition to the attitude towards EFL courses, Kahoot! can positively affect the attitude towards the school. Thus, it can be claimed that the attitudes of vocational high school students, who have a negative attitude towards the school in general (Atalay-Mazlum \& Balc1, 2018), can be changed positively with gamified digital-based activities. Finally, it is a limitation that the study participants were only males. The fact that our sample consisted of only males may have manipulated our results. Therefore, similar new research can be conducted with a mixed sample to provide more conclusive results evidence.

\section{Acknowledgement}

The data used in this study was confirmed by the researchers that it belongs to the years before 2020.

\section{Author Contribution Statement}

Merve SERCANOĞLU: implementation, data collection, review-writing and editing.

Yusuf İslam BOLAT: Conceptualization, methodology, data anaylsis, consultancy and control preliminary draft writing and editing.

İdris GÖKSU: Conceptualization, methodology, consultancy and control preliminary draft writing and editing.

\section{References}

Akın, A., Demirci, İ., \& Arslan, S. (2012). Revize edilmiş sınav kaygısı ölçeği: Geçerlik ve güvenirlik çalışması [Revised test anxiety scale: The validity and reliability study]. Journal of Educational Sciences E Practices, 11(21), 103-118.

Al-Hadithy, T., \& Ali, S. (2018, March). Gamification in learning English for academic purposes: Designing assessment for language using Kahoot with UAE undergraduate law students. 110th IASTEM International Conference. Toronto, Canada. 
Alsancak-Sırakaya, D. (2017). Oyunlaştırılmış tersyüz sınıf modeline yönelik öğrenci görüşleri [Student views on gamified flipped classroom model]. Ondokuz Mayis University Journal of Faculty of Education, 36(1), 114-136.

Atalay-Mazlum, A., \& Balcı, A. (2018). Meslek lisesi öğretmen ve öğrencilerine göre okul: Bir metafor çalışması [The school concept according to vocational high school teachers and students: a metaphor study]. Mehmet Akif Ersoy University Journal of Education Faculty, 47, 1-26. https://doi.org/10.21764/maeuefd.339901

Benson, J., \& El-Zahhar, N. (1994). Further refinement and validation of the revised test anxiety scale. Structural Equation Modeling: A Multidisciplinary Journal, 1(3), 203-221.

Bolat, Y. İ., Şimşek, Ö., \& Ülker, Ü. (2017). Oyunlaştırılmış çevrimiçi sınıf yanıtlama sisteminin akademik başarıya etkisi ve sisteme yönelik görüşler [The impact of gamified online classroom response system on academic achievement and views about this system]. Abant İzet Baysal University Journal of Education Faculty, 17(4), 1741-1761.

Budiati, B. (2017, May). ICT (Information and communication technology) use: kahoot program for english students' learning booster. Education and Language International Conference. http://jurnal.unissula.ac.id/index.php/ELIC/article/view/1225/934

Bury, B. (2017, November). Testing goes mobile - Web 2.0 formative assessment tools. ICT4LL 2017: International Conference ICT for Language Learning. Florence/Italy.

Can, A. (2014). SPSS ile bilimsel araştırma sürecinde nicel veri analizi [Quantitative data analysis in scientific research process with SPSS] (3rd ed.). Ankara: Pegem Akademi.

Chun, D., Kern, R., \& Smith, B. (2016). Technology in language use, language teaching, and language learning. The Modern Language Journal, 100(S1), 64-80.

Cornillie, F., Thorne, S. L., \& Desmet, P. (2012). ReCALL special issue: Digital games for language learning: Challenges and opportunities. ReCALL, 24(3), 243-256.

Creswell, J. W. (2013). Research design: Qualitative, quantitative, and mixed methods approaches. Thousand Oaks, CA: SAGE Publications.

Eltahir, M. E., Alsalhi, N. R., Al-Qatawneh, S., AlQudah, H. A., \& Jaradat, M. (2021). The impact of game-based learning (GBL) on students' motivation, engagement and academic performance on an Arabic language grammar course in higher education. Education and Information Technologies, 26(3), 3251-3278.

Figueroa Flores, J. F. (2015). Using gamification to enhance second language learning. Digital Education Review, (27), 32-54. https://doi.org/10.1344/der.2015.27.32-54

Gee, J. P. (2003). What video games have to teach us about learning and literacy. Computers in Entertainment, 1(1), 20. https://doi.org/10.1145/950566.950595

Good, T. L., \& Brophy, J. E. (2000). Looking in classrooms (8th ed.). NY: Longman.

Graham, K. (2015). TechMatters: Getting into Kahoot!(s): Exploring a game-based learning system to enhance student learning. LOEX Quarterly, 42(3), 6-7.

Gündüz, A. Y., \& Akkoyunlu, B. (2020). The gamification tool for the classroom response systems: Kahoot! Hacettepe University Journal of Education, 35(3), 480-488.

Howell, D. D., Tseng, D. C. Y., \& Colorado-Resa, J. T. (2017). Fast assessments with digital tools using multiple-choice questions. College Teaching, 65(3), 145-147.

Hubbard, P. (2009). Computer assisted language learning: Critical concepts in linguistics, Volumes I-IV. London \& New York: Routledge.

Iaremenko, N. V. (2017). Enhancing English language learners' motivation through online games. Information Technologies and Learning Tools, 59(3), 126-133.

Isbister, K., Karlesky, M., Frye, J., \& Rao, R. (2012). Scoop! A movement-based math game 
designed to reduce math anxiety. Conference on Human Factors in Computing Systems Proceedings, 1075-1078. https://doi.org/10.1145/2212776.2212389

Ismail, M. A. A., \& Mohammad, J. A. M. (2017). Kahoot: A promising tool for formative assessment in medical education. Education in Medicine Journal, 9(2), 19-26.

Johnson, L., Adams Becker, S., Estrada, V., \& Freeman, A. (2014). NMC Horizon Report: 2014 Higher education edition. https:/library.educause.edu//media/files/library/2014/1/hr2014-pdf.pdf

Kafai, Y. B. (2006). Playing and making games for learning. Games and Culture, 1(1), 36-40. https://doi.org/10.1177/1555412005281767

Kebritchi, M., Hirumi, A., \& Bai, H. (2010). The effects of modern mathematics computer games on mathematics achievement and class motivation. Computers and Education, 55(2), 427-443. https://doi.org/10.1016/j.compedu.2010.02.007

Kessler, G. (2018). Technology and the future of language teaching. Foreign Language Annals, 51(1), 205-218. https://doi.org/10.1111/flan.12318

Licorish, S. A., Owen, H. E., Daniel, B., \& George, J. L. (2018). Students' perception of Kahoot! 's influence on teaching and learning. Research and Practice in Technology Enhanced Learning, 13, Article 9. https://doi.org/10.1186/s41039-018-0078-8

Mavridis, A., \& Tsiatsos, T. (2017). Game-based assessment: investigating the impact on test anxiety and exam performance. Journal of Computer Assisted Learning, 33(2), 137-150.

McFarlane, A., Sparrowhawk, A., \& Heald, Y. (2002). Report on the educational use of games. $\quad$ Retrieved from http://questgarden.com/84/74/3/091102061307/files/teem_gamesined_full.pdf

Md. Yunus, M., \& Nur Rashidah, K. R. (2011). Motivation and attitudes for learning English among year six students in primary rural school. Procedia - Social and Behavioral Sciences, 15, 2631-2636. https://doi.org/10.1016/j.sbspro.2011.04.160

Medina, E. G. L., \& Hurtado, C. P. R. (2017). Kahoot! a digital tool for learning vocabulary in a language classroom. Revista Publicando, 12(1), 441-449.

Mehdiyev, E., Uğurlu, C. T., \& Usta, H. G. (2017). İngilizce dil öğreniminde güçlükler ölçeği geçerlik ve güvenirlik çalışması [The validity and reliability study of English language learning difficulties scale]. Journal of Theory and Practice in Education, 13(3), 411-429. https://doi.org/10.9761/JASSS3632

Nkhoma, C., Nkhoma, M., Thomas, S., Tu, L. K., \& Le, N. Q. (2018). Gamifying a flipped first year accounting classroom using Kahoot! International Journal of Information System and Engineering, 6(2), 93-115. https://doi.org/10.24924/ijise/2018.11/v6.iss2/93.115

Orhan-Göksün, D., \& Gürsoy, G. (2019). Comparing success and engagement in gamified learning experiences via Kahoot and Quizizz. Computers and Education, 135, 15-29.

Özkan, Z., \& Samur, Y. (2017). Oyunlaştırma yönteminin öğrencilerin motivasyonları üzerine etkisi [Effects on the students' motivations of using the gamification method in learning process: A content analysis study]. Ege Journal of Education, 18(2), 857-886.

Papastergiou, M. (2009). Exploring the potential of computer and video games for health and physical education: A literature review. Computers and Education, 53(3), 603-622.

Patton, M. Q. (1990). Qualitative evaluation and research methods (2nd ed.). SAGE Publications.

Plump, C. M., \& LaRosa, J. (2017). Using Kahoot! in the classroom to create engagement and active learning: A game-based technology solution for eLearning novices. Management Teaching Review, 2(2), 151-158. https://doi.org/10.1177/2379298116689783

Premarathne, P. B. T. K. (2017, October). A study on incorporating gamification into ESL classroom via Kahoot! International Conference on the Humanities (ICH). 
Prensky, M. (2001). Digital natives, digital immigrants Part 1. On the Horizon, 9(5), 1-6.

Purba, L. S. L., Sormin, E., Harefa, N., \& Sumiyati, S. (2019). Effectiveness of use of online games Kahoot! chemical to improve student learning motivation. Jurnal Pendidikan Kimia, 11(2), 57-66.

Putri, N. S. (2019). Kahoot application in English language teaching (ELT) context: An alternative learning strategy. ELSYA : Journal of English Language Studies, 1(1), 11-15.

Rosas, R., Nussbaum, M., Cumsille, P., Marianov, V., Correa, M., Flores, P., Grau, V., Lagos, F., Lopez, X., López, V., Rodriguez, P., \& Salinas, M. (2003). Beyond Nintendo: Design and assessment of educational video games for first and second grade students. Computers and Education, 40(1), 71-94. https://doi.org/10.1016/S0360-1315(02)00099-4

Şad, S. N., \& Özer, N. (2020). Using Kahoot! as a gamified formative assessment tool: A case study. International Journal of Academic Research in Education, 5(1), 43-57.

Susanti, S. (2018). Fun activities in teaching English by using Kahoot! Proceedings IAIN Batusangkar, 453-458.

Takkaç-Tulgar, A. (2018). İngilizce dersine yönelik tutum ölçeği geliştirilmesi: geçerlik ve güvenirlik çalışması [Development of a scale measuring attitudes towards english lesson: A study of reliability and validity]. Bingöl University Journal of Social Sciences Institute, 8(15), 233-244. https://doi.org/10.29029/busbed.354812

Thomas, M. (2012). Contextualizing digital game-based language learning: Transformational paradigm shift or business as usual? In M. Thomas (Ed.), Digital games in language learning and teaching (pp. 11-31). https://doi.org/10.1057/9781137005267_2

Thorne, S. L., Black, R. W., \& Sykes, J. M. (2009). Second language use, socialization, and learning in Internet interest communities and online gaming. The Modern Language Journal, 93(S1), 802-821. https://doi.org/10.1111/j.1540-4781.2009.00974.x

Wang, A. I. (2015). The wear out effect of a game-based student response system. Computers and Education, 82, 217-227. https://doi.org/10.1016/j.compedu.2014.11.004

Wang, A. I., \& Tahir, R. (2020). The effect of using Kahoot! for learning - A literature review. Computers and Education, 149, 103818. https://doi.org/10.1016/j.compedu.2020.103818

Yildirim, I. (2017). The effects of gamification-based teaching practices on student achievement and students' attitudes toward lessons. Internet and Higher Education, 33, 86-92. https://doi.org/10.1016/j.iheduc.2017.02.002

Yıldırım, A., \& Şimşek, H. (2013). Sosyal bilimlerde nitel araştırma yöntemleri [Qualitative research methods in the social sciences] (9th ed.). Ankara: Seçkin Publishing.

Yürük, N. (2020). Using Kahoot as a skill improvement technique in pronunciation. Journal of Language and Linguistic Studies, 16(1), 137-153. https://doi.org/10.17263/jlls.712669

Zengin, Y., Bars, M., \& Şimşek, Ö. (2017). Matematik öğretiminin biçimlendirici değerlendirme sürecinde Kahoot! ve Plickers uygulamalarının incelenmesi [Investigation of using Kahoot! and Plickers in formative evaluation process in mathematics teaching]. Ege Journal of Education, 18(2), 602-626.

Zin, N. A. M., Jaafar, A., \& Seng Yue, W. (2009). Digital game-based learning (DGBL) model and development methodology for teaching history. WSEAS Transactions on Computers Archive, 8, 322-333.

Copyright $\odot$ JCER

JCER's Publication Ethics and Publication Malpractice Statement are based, in large part, on the guidelines and standards developed by the Committee on Publication Ethics (COPE). This article is available under Creative Commons CC-BY 4.0 license (https://creativecommons.org/licenses/by/4.0/) 